\title{
Chapter 4 \\ Causes of the Shadow Economy
}

\author{
Milojko Arsić, Mihail Arandarenko, Branko Radulović, Saša Ranđelović, \\ and Irena Janković
}

\subsection{Causes of the Shadow Economy Rooted in the Tax System}

Of all the factors related to the design of the tax system and the institutional environment for its payment, collection, and administration, the following have the most significant impact on the extent of the shadow economy: size and structure of the tax burden; efficiency of the tax administration in collecting taxes; penalty policy; complexity and fairness of the tax system; and compliance costs.

\subsubsection{The Size of the Tax Burden}

According to the standard (Allingham-Sandmo) model of tax evasion, the size of the tax burden, along with the probability of detection of tax evasion and the possible sanctions, is a fundamental determinant of tax evasion, as well as of the shadow economy as a basis for tax evasion. According to this approach, increasing the tax burden makes it more cost-effective to operate in the informal sector. The total tax burden in Serbia is moderate (as measured by the ratio of tax revenue to GDP) and close to the averages of other Central and Eastern European countries. The situation is different, however, when individual forms of taxes are considered. Thus the general VAT rate is among the lowest in the region (even after the increase

M. Arsić $(\bowtie) \cdot$ M. Arandarenko • S. Ranđelović • I. Janković

Faculty of Economics, University of Belgrade, Belgrade, Serbia

e-mail: arsicm@ekof.bg.ac.rs; arandarenko@ekof.bg.ac.rs; randjelovic@ekof.bg.ac.rs;

irenaj@ekof.bg.ac.rs

B. Radulović

Faculty of Law, University of Belgrade, Belgrade, Serbia

e-mail: bradulovic@ius.bg.ac.rs 
to $20 \%$ ), while the reduced rate (at $8 \%$ ) is about average (Fiscal Council 2012). The rate of excise duty on oil products is slightly higher than the regional average, while the excise on tobacco products is at the level of the regional average (but lower than in developed countries); excise duty on most alcoholic beverages is at the level of the regional average or below. We can therefore conclude that the size of the tax burden on consumption in Serbia is no greater, on average, than in other Central and Eastern European countries, which leads us to conclude that the VAT tax burden is not an important cause of the greater extent of the shadow economy in Serbia in comparison to other countries in the region.

On the other hand, the fiscal burden on labour (as measured by the share of wage tax and social security contributions in total labour costs) is relatively high in Serbia, both in absolute terms and in relation to the country's level of development. This leads us to the conclusion that the size of the tax burden on income (particularly regarding social security contributions) is a major cause of the shadow economy in the field of wages, as well as of the corresponding tax gap in Serbia. Although the overall fiscal burden in Serbia is, realistically, moderate in relation to that in other Central and Eastern European countries, it is perceived as high by most businesses: many respondents in the survey carried out as part of this study identified high taxes as the third most significant cause of the large extent of the shadow economy. As legal entities mainly shift the VAT burden onto end-users, it is realistic to assume that most of them refer to the fiscal burden on labour when discussing fiscal burdens in general.

\subsubsection{The Fiscal Burden on Labour}

As for the fiscal burden on labour, it is particularly important to underline that, from a comparative standpoint, the labour tax wedge (calculated as the quotient of total wage tax and social contributions and total labour costs) is high at low wage levels and relatively low at high wage levels, a consequence of a proportional income tax system with a relatively small portion of non-taxable wage. At $33 \%$ of the average wage, the tax wedge in Serbia stands at $36.7 \%$. In Europe, recognised globally as the region with the highest taxes, only Sweden, Hungary, Romania, and the Federation of Bosnia-Herzegovina have greater tax wedges at those wage levels. At the level of the average wage, Serbia's tax wedge is around the European average. The progressiveness of labour taxation is very low: between 33 and $100 \%$ of the average wage, the tax wedge increases by just 2.6 percentage points, while in many European countries the increase is over 10 percentage points (Koettl 2012). It should be noted that taxation was even regressive between 2001 and 2007, with the tax wedge at the level of $33 \%$ of the average wage standing at as much as $47.1 \%$, while amounting to $42.2 \%$ at the level of the average wage (Arandarenko and Stanić 2006): which could serve as an explanation of the otherwise counterintuitive increase in informal employment seen between 2002 and 2007 (Krstić and Sanfey 2011). 
The high tax wedge for low-paid work is a natural incentive to sustain and increase informal employment. When informal businesses (including informal selfproprietorships) are formalised by moving into the formal sector they typically introduce salaries close to the minimum wage. If the tax burden is high at these wage levels, it is a clear obstacle to formalisation on the labour demand side. On the side of labour supply, the productivity of lower-qualified workers in lower-paid, labour-intensive sectors is low; so for many of them their salary is borderline 'costeffective' when compared to the alternatives, such as social welfare or work in the informal economy. In addition, the existence of a minimum social insurance contribution base (currently standing at $35 \%$ of the average wage) limits formal part-time employment.

\subsubsection{The Social Welfare System}

The social welfare system in Serbia is conceived in the traditional manner. Most importantly, welfare benefits are withdrawn at a ratio of 1:1 as reported income from labour increases. There is no employee benefits programme. Once a person loses the right to social welfare payments by virtue of finding employment, he or she must go through the entire demanding procedure of collecting documents and undergoing verification to become entitled to social welfare again. As a consequence, many beneficiaries of social welfare opt for a survival strategy where they combine these benefits with unreported, generally occasional, work. The rules of the tax/benefit system as presented here act in synergy to foster informal employment, and consequently the shadow economy.

\subsubsection{The Efficiency of the Tax Administration in Collecting Taxes}

The efficiency of the tax administration in collecting taxes is also an important determinant of the shadow economy, in the sense that greater probability of detecting tax evasion-all other considerations being equal-leads to a reduction in the shadow economy. Although there are no consistent and comparable data on the probability of detecting tax evasion in Serbia and other Central and Eastern European countries, we estimate, from the results of the survey, that it is relatively low in Serbia. A large number of taxpayers cite that the benefits of tax evasion are greater than potential losses if detected as 8th of the 11 key causes of the shadow economy. This does not mean that the Tax Administration is very effective in uncovering tax evasion, but rather that other factors are seen as more important in maintaining the shadow economy. 


\section{The Shadow Economy and Use of State Services Free of Charge}

The focus of most research on the shadow economy is on the environmental factors that affect whether individuals decide to take part in the shadow economy. However, it must be borne in mind that people have a propensity to evade paying taxes but to continue using social security, health, education and other services provided by the state. This propensity is borne out by both day-to-day experience and a substantial body of econometric and experimental research. Due to people's preference for free services, there would be tax evasion even if state services were completely aligned with public preferences. To tackle tax evasion, therefore, the elimination of environmental incentives must be accompanied by the establishment of an efficient evasion detection system, and non-selective prosecution of evaders caught. The propensity of the public to use services free of charge can to some degree be reduced by changing the population's values through outreach and the education system.

\subsubsection{The Penalties for Tax Evasion}

The penalties for tax evasion correlate negatively with the extent of the shadow economy and tax evasion: greater penalties, all other things being equal, bring about a reduction in the volume of the shadow economy and tax evasion. Empirical research shows that the impact of sanction policies on the extent of the shadow economy is lower than that of the probability of discovery (Alm et al. 1992), which leads to the conclusion that inadequate sanctions can be a cause, but not the key cause, of the shadow economy. The system of sanctions for tax evasion in Serbia is relatively well defined in statute, both as regards the penalties themselves and their imposition. Penalties for non-payment of taxes are defined as a function of the tax evaded (rather than of the undeclared tax base), which is an appropriate solution from the point of view of the sanction's desired aim. The sanctions for non-payment of taxes in Serbia comprise the basic penalty (fine or imprisonment) and interest for not having paid the taxes in due time. Although the statutory framework is not structurally deficient, the inappropriate and inconsistent application of the available penal mechanisms fosters the development of the shadow economy in Serbia. It has become standard practice for the Government to write off interest for late payment of taxes, provided that taxpayers continue paying tax regularly. This means that those taxpayers that pay their taxes regularly are put at a disadvantage, increasing moral hazard behaviour that negatively impacts their future readiness to comply with tax rules. 


\subsubsection{The Probability of Sanctions}

The probability of sanctions where evasion is detected also substantially affects the extent of the informal economy. Even with a well-designed statutory framework for sanctioning tax evasion the penalty system can remain an inefficient tool for tackling the shadow economy due to corruption, poor co-ordination between the Tax Administration and other government bodies, and lack of readiness and willingness on the part of the judiciary to process tax evasion cases, particularly with more complex evasion schemes ('VAT carousel' etc.). According to the results of the survey, this is also the case with Serbia, as more than two-thirds of all respondents felt that the probability of being penalised for tax evasion as provided for by law was very low, standing at the level of a random guess (50\%) or even lower.

\subsubsection{The Structure of the Tax System}

The structure of the tax system is an important factor in the extent of the shadow economy, in the sense that the level of informal activity is lower in countries where the public revenue system is based more on taxing consumption than on taxation of the factors of production. The reason for this lies in the fact that it is easier to evade taxes on the factors of production (particularly personal income tax). The share of taxes on consumption and those on the factors of production in total public revenues is nearly equal in Serbia, but a reform of the tax system involving a reduction in tax on labour and a revenue-neutral increase in consumption taxes could, among other positive economic effects, bring about a partial reduction in the general extent of the shadow economy.

\subsubsection{The Complexity of the Tax System}

In Serbia there is a large number of types of tax, and the system used to assess individual taxes is very complex. The more different streams of public revenue there are, and the more complex rules to assess and implement taxes, the lower the ability of tax inspectors to audit all types of tax, resulting in a lower probability of detecting tax evasion. In 2011 there were in excess of 370 various charges in Serbia, both fiscal and quasi-fiscal; most were administered by the Tax Administration of the Republic of Serbia and by local Public Revenue Administrations (NALED 2012a). In an environment dominated by such a large number of charges and with few qualified people auditing taxes, the complexity of the tax system is a major cause of the shadow economy. A large number of taxes, including many that are difficult to assess, can also lead to tax evasion by omission, as taxpayers may 
fail to comply because they are not aware of the requirements or lack the technical knowledge for tax self-assessment. The survey found that quasi-fiscal charges were seen as 5th of the 11 causes of the shadow economy, being ranked after macroeconomic and fiscal factors, lack of trust in the state, and corruption.

This system of quasi-fiscal charges has not been sufficiently transparent: unpredictable changes to it have been made and the main parameters of the charges (base, rate, taxpayer, etc.) have sometimes been arbitrarily defined according to the needs of different public authorities (Arsić et al. 2012). Quasi-fiscal charges have substantially distorted the operations of companies and entrepreneurs. ${ }^{1}$ The amount of these charges has often been out of proportion to the financial strength of the taxpayer, value of the service rendered to the taxpayer, amount of natural resources used by the taxpayer, and damage caused to the environment. As the fees and charges have, in some cases, been assessed at a much higher level than appropriate for the purpose of these instruments, they have often been primarily-and sometimes predominantly - taxes in nature. ${ }^{2}$ Apart from issues regarding the amounts of the charges, multiple quasi-fiscal fees have often been introduced that have similar purposes (same base, same taxpayer). In addition to introducing distortion, the quasi-fiscal charges have made a major contribution to the opaque tax system and growing tax compliance costs. These charges have to a large extent negated the positive effects of the low rates of basic taxes (corporate income tax, VAT). Some of the fees that have been a major burden in the private sector have had a direct bearing on the decision to start operating in the informal sector or to move a part or all of an operation into the shadow economy. The reform of the system of quasifiscal charges carried out in the second half of 2012 has been an important precondition for improving the business environment in Serbia, while the abolishment of some of these charges will certainly reduce start-up costs for small business entities. Appropriate categorisation and naming of the various charges, use of better parameters, and, above all, alignment of the charges with the financial strength of the taxpayer, will all have a major impact on motivating entities not to operate in the shadow economy. The statutory requirement for government bodies to set the amount of fees and charges for the following year by the end of third quarter of the current year could contribute to greater predictability of conditions for doing business in Serbia. Moreover, the proposed requirement to obtain the consent of the Ministry of Finance and Economy for any modification of fees and charges within the remit of local authorities or extra-budgetary institutions could prevent the uncontrolled growth of these burdens, which in the past has been a major incentive for taxpayers to attempt to circumvent them.

\footnotetext{
${ }^{1}$ According to the NALED study, the Government collected in excess of $2 \%$ of GDP through the charges inventoried, but it is clear that the number of these charges and their significance to the balance are greater.

${ }^{2}$ For instance, some classical taxes were treated by statute as fees: the construction land usage fee, which is a typical property tax, as well as the 'signboard fee', which is also a classical tax rather than a fee.
} 


\subsubsection{The Fairness of the Tax System}

A fair tax system subjects entities at similar levels of financial strength to similar tax burdens. In the Serbian tax system, and particularly in personal and corporate income tax, such fairness is often notably absent. Personal income from various sources is taxed differently, so that individuals with high income from capital are taxed at a lower rate than those with high income from work. There are many tax breaks available to business entities so that entities in different segments pay different levels of tax on the same amount of profit. The real or perceived lack of fairness in taxation is a major driver of resistance to paying taxes. Although the latest changes to the Corporate Income Tax Law, adopted in December 2012, removed a number of tax breaks, the most generous and most frequently used (such as investment tax credit) have been retained. Given the relatively low statutory tax rate, liberal tax breaks are an expensive (in terms of tax expenditure) and inefficient instrument for incentivising investment, as well as one that distorts business behaviour by continuing to treat entities of similar economic power differently.

\subsubsection{Tax Compliance Costs}

Tax compliance costs are, along with high tax burden, one of the major elements of expenses associated with tax compliance. When costs (time and money) associated with assessing, declaring, and paying taxes are high due to complicated procedures, lack of e-filing opportunities, etc., taxpayers are more incentivised to operate in the informal sector. Serbia is ranked 149th (of 185 countries) for ease of paying taxes in the World Bank's Doing Business 2012 survey: a decline in relation to last year and almost the worst result of all the countries in the region, as well as of all other areas of doing business in Serbia. The high tax compliance costs in Serbia are caused by the large number of payment procedures (as many as 66 times per year, compared to the Eastern European average of 28 times per year) and the substantial time cost of these activities (280 working hours per year, on average). Accordingly, it can be concluded that high tax compliance costs are also a major reason for the increase in the shadow economy in Serbia. According to estimates based on the standard cost model, costs of administering taxes account for $47 \%$ of all administrative costs (Radulović 2011b).

The contribution made by these causes to the extent of the shadow economy in Serbia is difficult to gauge, but can be approximately estimated on the basis of taxpayers' views and their perception of the importance of each of the above causes (Fig. 4.1).

According to the results of the survey, legal taxpaying entities believe that the economic crisis and fewer opportunities for employment, loss of confidence in the government and public institutions, and high taxes are the principal causes of 


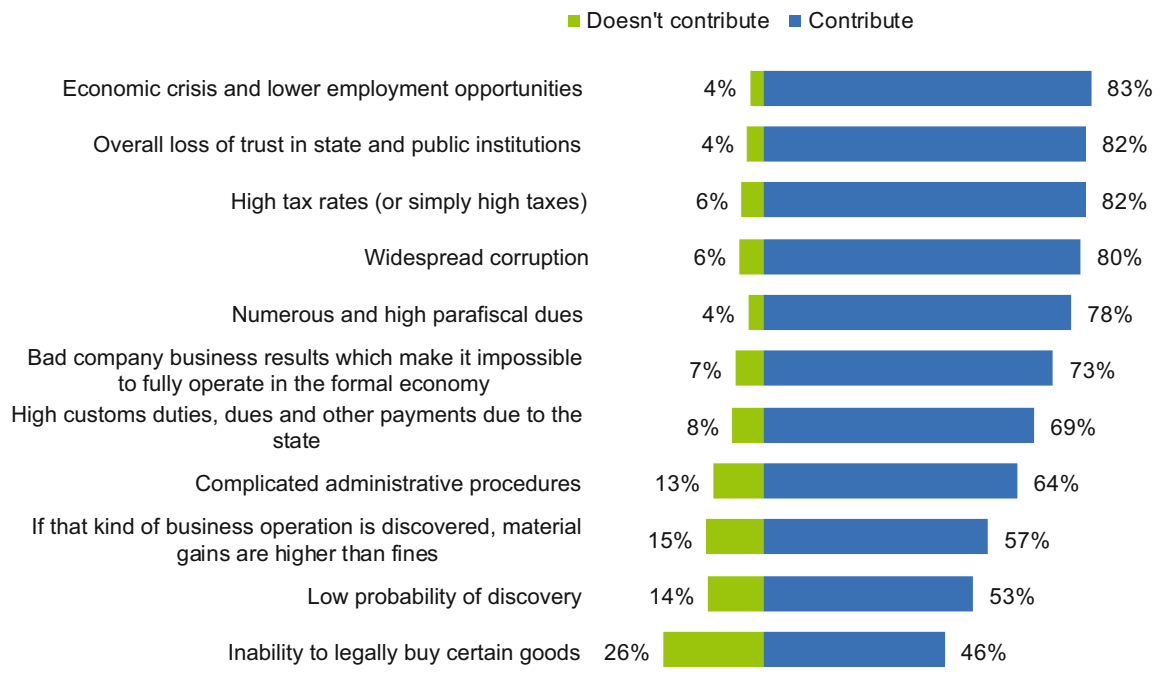

Fig. 4.1 Respondents' views on the contribution made by individual causes to the shadow economy in Serbia. Source: Own calculations. Survey on Conditions for Doing Business in Serbia, FREN, 2012

the shadow economy in Serbia. In addition, widespread corruption, numerous quasi-fiscal charges, and poor corporate performance are among the main causes. The problem of being unable to legally purchase certain goods is ranked least significant.

The taxpayer's decision whether or not to fully comply with their tax obligation depends on the objective situation regarding the causes of the shadow economy referred to above, and on their perception of that situation. The survey results on taxpayer views of the importance of the causes of the shadow economy is therefore also relevant in the context of designing measures aimed at tackling the shadow economy in Serbia.

\subsection{Labour Market Institutions as an Incentive to the Shadow Economy}

Recently it has often been claimed that rigid labour market regulation (particularly hiring and firing rules or more generally, employment protection legislation) is one of the major causes of the shadow economy. However, the regulatory framework for the labour market comprises a large number of other features whose impact on the shadow economy may be equally important. In this section we will briefly consider the influence of some of these diverse factors that we believe could, in their current form, foster the shadow economy. 


\subsubsection{Minimum Wage}

In the simplest theoretical context, the minimum wage in the competitive labour market can artificially constrain demand for labour. If an institutionally imposed lower wage limit means that it is not cost-effective for businesses to pay workers more than the wage that reflects their marginal productivity, such businesses will simply refuse to hire them. Those workers will either remain unemployed or will move to sectors without a minimum wage. If a uniform minimum wage applies across the entire formal sector, as is the case in Serbia, then the informal sector is the only way out for workers whose marginal productivity is lower than the minimum wage.

The amount of the minimum wage is one of the key parameters that define how many workers will be 'squeezed out' of the formal sector. The higher this wage (the amount of which is usually viewed in relation to the average wage, which also makes it comparable internationally), the greater the likelihood that more workers enter the informal sector. Between 2001 and 2010 the minimum wage in Serbia fluctuated in a relatively stable interval of between 35 and $40 \%$ of the average wage (Arandarenko and Avlijaš 2011), which, in international terms, is considered a moderate amount. However, 2011, and particularly 2012, saw a major increase in the minimum wage, which reached a level of approximately $50 \%$ of the average wage in 2012, making the minimum-to-average wage ratio in Serbia higher then the Western Balkans average (Kovtun et al. 2014). This is considered very high and can safely be said to be an incentive to informal employment.

\subsubsection{Working Hours}

The Labour Law stipulates rules governing working hours. This is a broad body of regulations that includes rules on the length of full-time, part-time, and shortened working hours, overtime and work on holidays, re-allocation of working hours, annual leave, daily rest periods, maternity leave, etc. Generally speaking, the more generous these provisions are to workers (shorter working hours, longer leave, greater reimbursement for overtime, etc.), ceteris paribus, the greater the cost to employers and the greater the incentive for them to partially or fully rely on informal workers to whom they can deny statutory rights. Typically, employers operating on the margins of formal sector will tend to extend the working hours of their employees, both formal and informal, without reimbursement for overtime or indeed any reimbursement at all; they are also prone to cutting workers' annual leave and ignoring statutory paid leave periods. It has also been observed that a shorter working week (e.g., of $35 \mathrm{~h}$, as in France) creates incentives for additional informal work among those in formal employment.

OECD (2008) concluded that, when compared to other nations, Serbia had in place balanced and neutral working hours regulations. The $40 \mathrm{~h}$ standard working 
week fits into the international average. The option of reducing the working week to $36 \mathrm{~h}$ is rarely used. From a comparative perspective, overtime is rather limited, with $8 \mathrm{~h}$ of overtime allowed per week. However, the law is more generous towards employers in terms of re-allocating working hours, since it allows them to require employees to work up to $60 \mathrm{~h} /$ week over a rather lengthy period of 6 months.

Thus working hours legislation in Serbia is comparable to the international average for countries at a similar level of development. It is part of a tradition spanning several decades that is rooted among both workers and employers and thus probably does not represent a major primary incentive for exclusion from the formal economy and/or participation in the informal economy.

\subsubsection{Employment Protection Legislation}

In a narrow sense, employment protection legislation (EPL) is made up of a set of provisions and procedures that apply to the termination of employees. It imposes statutory limitations on the termination of employees and governs compensation payable by employers to employees in the case of both individual and collective termination of open-ended employment contracts. Employment protection legislation has two main cost components: transfers, made up of severance payments and the obligatory notice period, and taxes, which entail the procedural costs of implementing EPL and the payments that need to be made to third parties, such as the state, courts, and legal experts or other consultants. In a broader sense, EPL also includes statutory regulation of hiring rules, including statutory limitations that can be imposed through atypical employment contracts and that limit employee rights in relation to those enjoyed by workers on open-ended employment contracts. In general, the stricter the EPL the greater the incentive for businesses to employ informal workers.

A composite EPL index, developed by the OECD, is used for international comparison of the level of strictness of this framework. Although World Bank and OECD (2008) research found that Serbia had an EPL index of 2.4 (on a scale from 0 to 6 , with 0 being the most liberal and 6 the most rigid level of regulation), which is close to the average of OECD countries including comparable Central and Eastern European nations, there are specific and important aspects of EPL that are widely held to have a possible negative impact on formal employment.

Firstly, the amount of the statutory severance pay applicable in Serbia is linked to the entire years of service of an employee, rather than on the years of service with any one employer. This solution is nearly unique globally and must have a detrimental impact on the formal employment of elderly workers, although the intent of the legislator was surely quite the opposite, as it makes it more expensive to fire workers with more years of service.

Secondly, another harmful rule often cited is that under which the most a fixedterm employment contract can be extended is up to 1 year, after which the employer is required either to terminate the employee or to change their contract to an open- 
ended one. From a global perspective, most countries now allow fixed-term contracts that last or can be extended for more than 1 year as a result of efforts to increase labour market flexibility. However, in practice most companies in Serbia have been known to break this rule with impunity by changing job titles and thus circumventing the statutory provision.

It is interesting to note that the respondents in the Survey on Conditions for Doing Business in Serbia stated that, among the most significant factors that constrain doing business, labour legislation was only marginally restrictive: a mere $3 \%$ of total respondents included labour legislation among the largest constraints. In addition, when respondents were asked what would improve the employee registration process and increase their total wages, $38 \%$ cited a cut in wage taxes and $38 \%$ a cut in contributions, while just $5 \%$ mentioned changes to labour legislation making it easier to terminate workers.

\subsubsection{Unemployment Benefits}

These benefits are a reserve source of income for workers who lose their jobs, designed to help protect their standard of living and to enable them to devote all of their time to looking for a new job. They therefore represent a natural extension of employment protection legislation during the time that a worker is unemployed. Yet, since entitlement to unemployment benefits is lost when a new formal job is found, beneficiaries are incentivised to combine these benefits and income from informal employment until their unemployment benefits expire.

The new 2009 Law on Employment and Unemployment Insurance reduced these incentives in several aspects. Firstly, the extent of these benefits was reduced by cutting the maximum period to 1 year (or, exceptionally, 2 years for people meeting at least one condition for retirement at the time they lose their job), as well as by establishing lower minimum and maximum benefit amounts ranging from 80 to $160 \%$ of the minimum wage, respectively. Secondly, incentives were introduced for finding formal employment before the expiry of the benefit period in the form of $30 \%$ of the amount that would have been paid if the right to benefits had been exercised to the fullest extent.

As current statutory provisions governing these benefits are comparable with European and regional practice, in addition to which few countries have incentives for early re-employment, the that current rules cannot be changed substantially when it comes to statutorily guaranteed rights. There has, however, been criticism of the National Employment Service, which is believed by some not to be sufficiently efficient in supervising active job seeking by unemployment beneficiaries. 


\subsubsection{Retirement Rules}

The parameters governing Serbia's pension system include a relatively low minimum retirement age. In addition, there is no actuarial penalty for early retirement. This creates incentives for people to continue working after retiring, primarily in the informal sector, as formal work by pensioners is highly restricted. The standard retirement age in Serbia is lower than in most other European countries (particularly for women), while the difference between the standard and minimum age is among the greatest, which indicates that this factor could substantially affect the shadow economy among the Serbian population. The minimum retirement age in Serbia is 55 years, or even lower in some sectors of activity (such as the military and the police); thus people who retire relatively young continue working, mainly in the informal sector.

\subsection{Other Institutional and Economic Causes of the Shadow Economy in Serbia}

The following institutional and economic factors have been estimated to have the greatest impact on the extent of the shadow economy in Serbia: low productivity, the economic crisis and widespread lack of liquidity, inefficient market exit mechanism, high administrative burden, poor regulatory environment and legal insecurity, construction permits for both existing buildings ('legalisation') and new construction, low quality of public services, large number of small business entities, structure of the population's income, high levels of corruption, high tolerance for the shadow economy by the state, high unemployment rate, and low tax morality. ${ }^{3}$

\subsubsection{Low Productivity}

According to the World Bank (2009), the productivity of Serbian businesses (value added per worker) is much lower and their unit costs are much higher than in other countries in the region. ${ }^{4}$ Low productivity, coupled with other factors, causes a

\footnotetext{
${ }^{3}$ For an overview of the relevant causes of the shadow economy, see Schneider and Enste (2000), and GIZ (2010).

${ }^{4}$ Between 2007 and 2009 the added value per worker in Serbia was $€ 12,837$ per annum, or on average less than half of the figure recorded in Slovakia (€25,043), or slightly less than half of the amount for Hungary ( $€ 20,812$ ). In addition, unlike the situation in EU countries-where mediumsized and large businesses are much more productive than small ones-workers in Serbia's medium-sized businesses are less productive by as much as $20 \%$ than employees in small businesses, while large businesses are only slightly more productive (by a mere $5 \%$ ). The
} 
vicious circle in which low productivity makes business entities turn to the informal sector, which, as a rule, decreases productivity further. ${ }^{5}$ In these circumstances, the business model of many companies means they can be profitable (or, indeed, even survive) only if they fail to comply with their tax obligations, either wholly or in part. $^{6}$

\subsubsection{Economic Crisis and Widespread Lack of Liquidity}

In an environment dominated by the economic crisis and a major decline in demand, a number of business entities have been forced to adjust their operations to the emerging circumstances. Some businesses that used to be profitable before the crisis have now been forced to move at least part of their activities into the shadow economy to be able to continue doing business. Other business entities are faced with poor liquidity. ${ }^{7}$ Due to widespread liquidity problems, business entities that pay taxes in Serbia often opt for partial compliance with tax legislation, either not paying regularly or not paying the amounts required, giving preference instead to meeting their obligations arising from commercial transactions. To be able to be selective in their payments, business entities often shift part of their operations into the shadow economy and pay their debts according to the significance of each particular creditor to their business. According to the findings of the survey, the economic crisis was identified as the single most important cause of the shadow economy.

difference is even greater when particular sectors are observed (e.g., manufacturing) (World Bank 2011).

${ }^{5}$ Multiple reasons for the lower productivity of the informal sector are usually cited in literature. The first one is the informal sector's limited access to finance. Poorer access to formal finance (see the last section of this chapter) forces these entities to seek finance from more expensive informal sources, or to rely exclusively on their own sources of finance (including borrowing from family and friends). Limited access to finance means that these companies employ less capital: this in turn means that they cannot be more efficient due to division of labour, or achieve economies of scale and size. Consequently, business entities operating in the informal sector tend to use labourintensive means of production and have lower productivity. The second reason is that the informal sector, as a rule, retains a less productive workforce. The third factor is that these entities cannot seek protection from the state (say, if informal contracts are not met), nor do they have access to the various forms of assistance provided by the state. Finally, these business entities are often unable to report corruption in government bodies, and are thus frequently forced to bribe corrupt officials themselves.

${ }^{6}$ As taxes account for less than $10 \%$ of total expenditure, businesses must include all relevant costs—including taxes—into their business models (Ranđelović and Đorđević 2012).

${ }^{7}$ One should bear in mind the fact that, in the minds of business people, the economic crisis can to a large extent be equated with issues of poor liquidity (and insolvency) faced by the corporate sector. 


\subsubsection{Inefficient Market Exit}

The already-mentioned issue of poor efficiency and substantial liquidity shortages should lead to an orderly exit of businesses from the market, through either insolvency (bankruptcy) or voluntary liquidation. Reforms of the insolvency procedure have resulted in some progress, both in terms of the duration and cost of the proceedings and the number of insolvency cases (primarily owing to the application of 'automatic bankruptcy'), and have also brought about a major reduction in the number of insolvent businesses (i.e., businesses whose bank accounts have been frozen). Nevertheless, the late initiation of formal insolvency proceedings or the lack of such proceedings has made it possible for a number of debtors whose bank accounts have been frozen to continue operating, mainly in the informal sector. In mid-2012 the Constitutional Court declared the 'automatic bankruptcy' provisions of the Bankruptcy Law unconstitutional. This ruling will lead to a renewed increase in the number of businesses with illiquidity problems, some of which will be forced to continue operating in the informal sector. ${ }^{8}$

Another problem also present in Serbia is the so-called 'phoenix company' mechanism, where businesses keep their debts vested in the old business while their assets are transferred to a new business (or they temporarily move the business into the shadow economy) and then de facto wind the old business up. In practice this often takes place with no sanctions for the owner. 'Phoenix companies' most often do business with small and medium-sized businesses and cause them substantial liquidity problems. To be able to survive, the victims of "phoenix companies' themselves rely on moving part of their operations into the shadow economy.

\subsubsection{High Administrative Burden}

A high administrative burden incentivises businesses and individuals to do business in the informal sector. Empirical findings show a substantial positive correlation between the regulatory burden imposed on the private sector and the extent of the shadow economy. ${ }^{9}$ Some authors (e.g., Friedman et al. 2000) even believe that

\footnotetext{
${ }^{8}$ Provisions on automatic insolvency (as governed by the Bankruptcy Law, Official Gazette of the Republic of Serbia Nos. 104/2009, 99/2011—other law, and 71/2012-Constitutional Court ruling) have been repealed. This has made it possible for debtors whose accounts have been frozen due to non-payment for more than 1 year to continue operating.

${ }^{9}$ Johnson et al. (1998) showed that changes to the regulatory environment (as measured using the regulation index, which ranges between 1 and 5) have a major impact on the share of the shadow economy. A one-point change in the index will lead to an increase of $8.1 \%$ in the share of the shadow economy. Enste (2010) used a comprehensive regulation index (comprising regulation of the labour and goods market, and the quality of institutions) to also analyse the relationship between the regulatory environment and the shadow economy. The findings, based on research into 25 OECD member countries, show that regulation is one of the main factors that determine the extent of the shadow economy, in addition to the tax wedge and tax morality.
} 
Table 4.1 Comparison of administrative costs and extent of shadow economy

\begin{tabular}{l|l|l}
\hline Country & Administrative costs (\% of GDP) & Shadow economy (\% of GDP) \\
\hline Serbia (2010) & 4.0 & 30.1 \\
\hline Denmark (2006) & 2.2 & 17.0 \\
\hline Netherlands (2003) & 3.6 & 13.3 \\
\hline Czech Republic (2005) & 3.0 & 17.8 \\
\hline Austria (2006) & 2.8 & 9.6 \\
\hline
\end{tabular}

Sources: For the share of administrative costs in GDP in Serbia, see Radulović (2011b); for the Netherlands, see Netherlands Bureau for Economic Policy Analysis, CPB (2004), Reducing the administrative burden in the European Union, CPB Memorandum; for Denmark, see SCM Network (2006), Information about the Danish SCM measurements; for the Czech Republic, see Office of the Government of the Czech Republic (2006), Regulatory Reform in the Czech Republic. For the shadow economy, see Schneider et al. (2010), except for Serbia, for which see Chap. 4 of this study

entrepreneurs base their decision as to whether or not to enter the informal sector more on their desire to avoid bureaucracy (and corruption) than to evade paying taxes. ${ }^{10}$ The administrative burden is considered to be one of the major causes of the shadow economy in Serbia. The administrative costs of doing business in Serbiaestimated between 3.8 and $4.2 \%$ (Radulović 2011b)—put it at the top of the list of countries that have made similar measurements. Table 4.1 shows a comparison of the share of administrative costs and the shadow economy in GDP in selected countries. $^{11}$

However, it is interesting that in the Survey on Conditions for Doing Business in Serbia, carried out for the purposes of this study, complex administrative procedures were ranked 'only' eighth in the list of causes of the shadow economy, behind macroeconomic and tax factors, as well as behind corruption and lack of trust in the state (Fig. 4.1). When analysing the findings of this study we should take into account the fact that the respondents came from businesses that operate, as a rule, mainly or even wholly in the formal economy. Hence, we cannot conclude that complex administrative procedures have ceased to be a major factor for those still remaining outside the formal market.

\subsubsection{Poor Regulatory Environment and Legal Insecurity}

In assessing the regulatory burden we should bear in mind the fact that it is not just the burden that matters (in terms of money and time spent on compliance, etc.): it is

\footnotetext{
${ }^{10}$ The findings of Friedman et al. (2000) indicate a substantial link between various indicators of the regulatory burden and the extent of the shadow economy: more regulation means a larger shadow economy.

${ }^{11}$ One should exercise caution when comparing these data, due to the different methodologies used to calculate administrative costs. The standard cost model is treated in greater detail and a comparison of methodologies by country is given in Radulović (2011a).
} 
also the quality of the regulatory environment that is important. ${ }^{12}$ Where the regulatory environment is poor, and the regulatory burden great, business entities will tend to shift at least part of their activities into the shadow economy. In this context, Enste (2010) cites the advantages of deregulation over other instruments aimed at reducing the extent of the informal economy. On the one hand, tax policy and the social security system are much more difficult to reform, due to the rigidity of the need to finance public goods and services and the political sensitivity of such reforms. On the other, deregulation does not bring about an increase in the budget deficit, while at the same time removing constraints and creating greater freedom of choice in how to do business, thereby directly contributing to the shadow economy becoming a less attractive option.

The findings of the survey show that "frequent legislative changes and imposition of unnecessary costs by the state" were cited by business entities as the second most important problem when doing business (a total of $41 \%$ ). As regulatory expenses are mainly fixed, they theoretically affect small businesses the most. There are multiple causes of the low quality of the regulatory environment and legal insecurity in Serbia, the most important being lateness in adopting bylaws, inadequate consultation with the private sector, and poor analysis and drafting process. One of the main causes of legal insecurity is lateness in adopting bylaws, which makes it impossible to implement the laws, while simultaneously old legislation lapses. ${ }^{13}$ Faced with this legal vacuum, business entities are often forced to operate not knowing whether they are operating in accordance with the law or if their activities fall within the scope of the shadow economy. The second cause of the poor regulatory environment is the frequent lack of publicity and consultations with the private sector in designing new legislation. According to analyses carried out by Transparency Serbia (2012), statutory provisions governing public comment periods in Serbia are inadequate. Among other things, there is no pre-defined form of public debate, nor are there sanctions in the event that a public body fails to launch such a debate. ${ }^{14}$ Non-compliance with the law by public authorities is compounded by the frequently passive stance of business entities. Businesses often lack the time and resources needed to take part, or simply do not feel that they can change anything. Besides, the frequent use of urgent law-making procedure in adopting legislation makes any kind of public participation difficult. In 2012 as many as 45 of the 55 laws affecting the business environment were adopted

\footnotetext{
${ }^{12}$ Loayza et al. (2006) state that "Countries with better institutions tend to create regulatory environments genuinely aimed to improve business conditions rather than privilege a few interest groups. They are also more likely to enforce regulation in a transparent and even-handed manner, limiting the regulator's margin for arbitrariness and corruption". Unfortunately, this does not apply to the Republic of Serbia.

${ }^{13}$ According to analysis carried out by NALED in 2012 (NALED 2012b), only three bylaws were adopted before the deadline, 33 were adopted after the deadline, and in 163 cases the deadline expired before the bylaws were adopted. Some bylaws were more than 2 years late.

${ }^{14}$ The last instance of a consultation process related to the package of tax laws adopted in late 2012.
} 
under urgent procedure. The lack of transparency and abuse of urgent procedure often result in inadequate statutory provisions (of which the administrative costs mentioned above are just one part) that make it difficult or impossible for the private sector to operate normally. Finally, the very manner of analysing and drafting legislation is also often poor. Even when there are formal regulatory impact analysis (RIA) reports that are part of the explanatory notes accompanying a proposed piece of legislation, the quality of such analysis is often questionable, as it is not carried out simultaneously with the law drafting and, as a rule, does not contain any type of quantitative assessment of the impact (costs and benefits) on the private sector. The current manner of drafting and adopting legislation does not contain appropriate mechanisms to prevent the adoption of legislation containing unnecessary regulatory requirements, while criteria guiding the authorities tasked with appraising the adequacy of analyses and the regulatory impact on business are excessively mild. ${ }^{15}$

\subsubsection{Construction Permit Issues for Existing Buildings ('Legalisation') and New Construction}

According to a recent study entitled Assessment of Constraints on Construction Permits in Serbia (USAID 2012b), investors often face difficulties in establishing title to tracts of land due to complex and often unclear restitution, 'legalisation', and conversion procedures. Unclear and complex 'legalisation' of buildings (i.e., issuance of construction permits for buildings constructed without appropriate approval) hinders access to the formal sector and commencement of legal operations, which means that some resources are placed completely beyond the scope of legal transactions and use in the formal economy. This leads to the well-known consequences described in de Soto $(1989,2000)$. According to data made available by the Ministry of Construction and Urban Planning, there are more than 700,000 unpermitted buildings in Serbia. In addition to legalisation issues, market entry is also hindered by the very complex construction permit system that entails filing for approval with a large number of bodies. ${ }^{16}$ The construction permit procedure is

\footnotetext{
${ }^{15}$ For instance, the Office of Regulatory Reform and Regulatory Impact Analysis received only 67 draft bills throughout 2012. Of these, the Office found that 24 contained impact analyses; 37 were provided with partial analyses; no analysis was required in three cases; while another three cases did not contain such analysis. Even the three bills missing RIAs were able to enter law-making procedure after the appropriate government committee so resolved. This means that 'filtering' legislation by quality does not function appropriately.

${ }^{16}$ According to the construction permitting study carried out by the USAID Business Enabling Project (BEP 2012b), 52 steps are typically needed to obtain a construction permit for an industrial company. Public businesses and other public authorities are in charge of as many as $90 \%$ of these procedures; there are as many as 20 different bodies exercising public powers that take part in the procedure.
} 
inefficient and lengthy; unable to obtain permits the proper way, a number of business entities start construction on their own initiative, thereby assuming a great deal of risk. In these circumstances they engage workers from the informal sector and businesses and entrepreneurs who do not report their work. The results of the survey carried out for the purposes of this study bear out the above conclusions. In addition to the pronounced extent of the shadow economy in the construction sector, this industry was also noted for a number of other responses (e.g., costcutting due to unfair competition is more pronounced in construction, as is operation without appropriate permits, etc.).

\subsubsection{Quality of Public Services}

Quality of public services correlates negatively with the extent of the shadow economy, with greater quality of public services implying greater readiness by the public to pay taxes, as those taxes go towards financing goods and services that meet their needs appropriately. Since relevant international studies show that the quality of general public services (healthcare, education, efficiency of public administration, efficiency of the justice system, etc.) is lower in Serbia than in most other European countries (World Bank 2009), the readiness of taxpayers to pay taxes in the manner and amounts set by law is also lower. The results of the survey show that the lack of trust in the state and public institutions is the second most important cause of the shadow economy in Serbia. Given that the degree of trust in the state reflects the degree of taxpayer satisfaction with the way that the state functions (and the quality of public goods it provides), it can be concluded that this is one of the major causes of the shadow economy in Serbia.

\subsubsection{High Levels of Corruption}

High levels of corruption disincentivise taxpayers from paying taxes, since the impression corruption creates is that those taxes will not be used to adequately finance the public sector, but will rather result in private gain by certain categories of people. Serbia has been ranked 86th (out of a total of 183 countries) in the global corruption perceptions index, indicating a high level of perceived corruption in society and, consequently, lower willingness of the public to pay their taxes. In addition, our survey found that respondents ranked corruption as the fourth most important cause of the shadow economy in Serbia. 


\subsubsection{High Tolerance for the Shadow Economy by the Government}

Many forms of the shadow economy are visible and could be tackled with relative ease. However, for a multitude of reasons, the Serbian Government has been postponing measures aimed at doing so. Thus, for instance, new (unused) industrial products are generally sold in flea and farmers' markets where taxes are evaded partially or wholly. The government tolerates these activities, as it views them as social welfare of sorts, aimed at the unemployed. Non-taxation of property is motivated more by political than by social reasons (e.g., local authorities avoid realistically estimating market values of real estate for tax purposes or avoid taxing all real estate in their areas in order to gain the political support of the electorate).

\subsubsection{Large Number of Small Business Entities}

The large number of small business entities has an adverse impact on the extent of the shadow economy, as more taxpayers mean that the Tax Administration is less likely to audit any one of them, which serves as an incentive for tax evasion. Empirical research carried out worldwide, including in Serbia (see Chap. 6 of this study) shows that the shadow economy is at its most widespread with entrepreneurs and small and micro-businesses (Tedds 2010; Williams 2006). Although comparative data indicate that the structure of Serbia's economy, in terms of the number of small, medium-sized, and large businesses, is similar to that of EU member states, it has been estimated that the current ratio of Tax Administration staff effectively engaged in tax audit to the number of taxpayers is relatively unfavourable. This contributes to the relatively low perceived probability of the discovery of tax evasion (issues faced by the Tax Administration will be covered in greater detail in Chap. 8 of this study). The unfavourable ratio of tax inspectors to number of taxpayers potentially subject to audit is primarily the consequence of the poor staffing structure of the Tax Administration, where only slightly more than $10 \%$ of staff are tasked with performing audits. In view of this, reorganising the Tax Administration to substantially increase the number of staff engaged in audits and improve their skills, while at the same time reducing the number of employees charged with administrative duties, would be an improvement of the current situation.

\subsubsection{The Structure of the Population's Income}

The structure of the population's income affects the extent of the shadow economy because of the differentiation in tax collection mechanisms by amount of income. 
The structure of the population's income is closely linked to the relative significance of individual forms of incorporation in the economy: companies, entrepreneurs, and agricultural estates. Thus the level of evasion of tax on income from wage-employment is much lower in Serbia than that of the tax on income from selfemployment (paid by farmers, entrepreneurs, etc.), since income from wageemployment is generally taxed at source by means of withholding a portion of income, while tax on income from self-employment is generally either selfassessed or payable when assessed by the Tax Authorities. In addition, states with a greater share of agriculture in GDP have greater volumes of the shadow economy on average, since the consumption of own products is not taxed.

\subsubsection{A High Unemployment Rate}

A high unemployment rate makes labour supply inelastic, meaning that the unemployed, with few opportunities to find employment in the formal labour market, consent to informal work that does not involve the payment of taxes and contributions on their wages (nor the rights arising from the payment of such dues). At $26.1 \%$, according to the Labour Force Survey, the unemployment rate in Serbia is among the highest in Europe (similarly high unemployment rates are seen only in Spain, Italy, Macedonia, and Greece). This factor has a major impact on the extent of the informal economy in Serbia, particularly in the field of employment.

\subsubsection{Tax Morality}

Tax morality defined as the readiness of a taxpayer to pay taxes in full and on time and thus pay in full for the public goods and services provided by the government, also has a substantial effect on the extent of the shadow economy. Hence, in countries with a low degree of trust in government institutions and their fairness and efficiency (such as Serbia) tax morality is also low, which adversely impacts the volume of the shadow economy. Low tax morality is also caused by the government's high tolerance for the shadow economy. However, the results of the survey show that 'just' $9 \%$ of all respondents believe that operating informally is justified in full or to a large degree. 


\subsection{Incentives from the Financial Sector}

The major factors that indirectly support the shadow economy within the system include the significant share of cash transactions in the total volume of payments, informal finance, and unregistered remittance inflows sent by migrants from abroad.

\subsubsection{Cash Transactions}

Cash represents a means that enables informal operations. ${ }^{17}$ Cash transactions include off-account payments that often occur informally and in foreign currency (in dollarized economies). As a rule, countries where the use of electronic money is more widespread see substantially lower volumes of shadow economy. According to the findings of Schneider (2011a), a $10 \%$ increase in the share of electronic payments will lead to a $5 \%$ drop in the shadow economy. Payments in cash still account for a large portion of total payments made in Serbia, although they have been seeing a downward trend over the past 5 years. According to NBS data for Q3 2012, more than six million payment cards (debit, credit, and corporate cards) have been issued in Serbia, with the number of active cards (with at least one payment during the previous quarter) standing at 2.7 million. Between 2007 and 2011 an increase of $56 \%$ in the number of transactions at cashpoints and points-of-sale involving cards issued in Serbia was recorded (a rise from 75 to 132 million transactions). However, of the total turnover of RSD 534 billion, as much as RSD 372.5 billion, or some $70 \%$, is accounted for by cash withdrawals.

Seen in this context, Serbia is characterised by an extremely high degree of euroisation (IMF 2011). According to the NBS report, in late March 2012 the degree of dinarisation of the Serbian financial system, measured as the share of dinar lending in total corporate and household lending, stood at $27.9 \%$ (NBS 2012). ${ }^{18}$ As the formal sector is euroised, a large number of transactions in the informal sector also take place in euros. It is quite common to pay for, say, more valuable services provided by tradesmen, or minor construction work etc., in euros. In addition to the fiscal motives discussed above, euroisation provides clear (non-fiscal) incentives for transactions to take place in the informal sector. Payments in foreign currency, instead of in dinars, in the informal sector avoid commission fees charged by banks and the differences in the exchange rates applied

\footnotetext{
${ }^{17}$ According to Schneider (2011b), "Countries with high levels of electronic payment usage, such as the United Kingdom and the Netherlands, have smaller shadow economies than those with minimal levels of electronic payments, such as Bulgaria and Romania."

${ }^{18}$ In addition to the fact that the share of the dinar measured in this way is less than one-third, it should be borne in mind that the bulk of dinar-denominated loans are actually those subsidised by the state.
} 
by banks when buying and selling foreign currency (for instance, when a business entity issues a foreign currency sales order to the bank where it keeps its foreign currency assets, whereupon the bank pays the appropriate dinar amount to the payee's dinar-denominated account). ${ }^{19}$

\subsubsection{Informal Finance}

Informal finance is a phenomenon that accompanies the large extent of the shadow economy in developing countries. The reasons for its existence are poor local legislation and enforcement regulations, market entry barriers, expensive formal financing sources, lack of finance products that meet beneficiaries' needs, inappropriate tax legislation, and high tax rates (USAID 2005, 2012a). The consequences of informal finance are reflected in greater information asymmetries between market participants, lack of tax revenue derived from this area, and exclusion of formal financial intermediaries from the funds transfer process. This has a negative effect on the development of the financial sector and the efficient allocation of financial resources to recipients. Low efficiency, lack of transparency, and greater uncertainty reduce the trust of the participants in the system, which leads to less readiness to embark on new projects and invest: this in turn has adverse repercussions on the growth of the economy as a whole. Thus it is in the interest of economic policymakers to disincentivise informal financing channels in parallel with efforts aimed at tackling the informal economy, and to foster financing through existing formal channels and the development of new ones. This would reduce uncertainty, enhance the efficiency of allocation of funds received, boost employment, and increase tax revenues generated by formal activity. A greater finance supply should result in lower financing costs, which could increase the availability of these funds, primarily to entrepreneurs and small and medium-sized businesses, which are among the main drivers of new cycles of economic activity in developing countries. A major role in this process, in addition to the private sector, should be played by various forms of public-private partnership, as well as by special development institutions.

According to one of the initiatives announced by the Serbian Ministry of Finance and Economy, the state will acquire up to $25 \%$ of the equity of a number of primarily export-oriented SMEs that cannot secure appropriate financing. Businesses with the best investment programmes will be eligible to apply for this support, while the Serbian Export Credit and Insurance Agency (AOFI) will be in charge of the technical arrangements. The key issue in determining the success of

\footnotetext{
${ }^{19}$ The Foreign Currency Operations Law (Official Gazette of the Republic of Serbia, Nos. 62/2006 and 31/2011) stipulates, among other things, that incoming and outgoing payments and transfers between residents and non-residents in Serbia must be made in dinars, save for particular cases listed in Article 34(2), in which foreign currency may be used.
} 
this programme will certainly be the need to reduce the moral hazard risk involved in distributing the limited funds available in the budget.

Alternatively, Serbia could gradually shift to the globally accepted practice of establishing institutions providing micro-finance to entrepreneurs and SMEs that find traditional borrowing either inaccessible or too costly. Originally envisaged as non-profit entities owned by the very people most at risk and in need of financing to start their businesses, these institutions can take the form of either co-operatives or credit unions. They can also formally be incorporated as non-governmental organisations or savings banks, or can even be owned by the government as sectororiented banks (e.g., agricultural development banks, rural banks, etc.). The key issue and precondition for establishing these specialised entities essentially remains similar to that for the proposal to establish a single Serbian Development Bank: it is necessary to design appropriate laws and bylaws to prevent corruption in allocating funds, and ensure professionalism and efficiency in managing the limited resources available to such an entity.

As shown by the survey of businesses and entrepreneurs in Serbia, one of the major constraints on doing business is access to formal financing, as well as weak purchasing power, frequent changes to legislation, high tax rates, inflation, and political instability. Most business entities are financed from net profits (92\%), while slightly more than one-quarter borrow from banks $(24 \%)$. Business entities tend to borrow either from banks or from their owners, while entrepreneurs rely on funds borrowed from individuals, friends, or family members. Another initiative of the Ministry of Finance and Economy current in 2013, which should facilitate access to liquid financing, is a programme of subsidised liquidity loans, which will be aimed at SMEs.

Slightly more than half of all business entities surveyed believe that financing in their sector of activity came in part from informal sources on which no tax is paid; the estimated share of informal investment was up to $50 \%$ of the total investment. On the other hand, such financing was rarely admitted when respondents spoke about their own operations. Only one-fifth of all business entities stated that investment in their companies came in part from informal financing (with up to $30 \%$ of the sum total of investments), while $66 \%$ claimed that no such financing was invested in their company.

\subsubsection{Unregistered Remittances Sent by Migrants from Abroad}

These represent a particularly important source of foreign capital in developing countries, which in absolute amounts often exceeds other forms of capital inflow from both private and public sources (Adams and Page 2005; Irving et al. 2010; Abdih et al. 2009, 2012). As the greatest volume of remittances enters most developing countries mainly through informal channels, better knowledge of the 
features of these transfers is necessary if they are to be formalised and directed into productive activities in the recipient country. ${ }^{20}$

Remittances were undoubtedly the largest source of financial inflows into Serbia during and after the global crisis. According to data for the period 2007-2011, inflows of remittances reached $€ 2.5-4$ billion annually. The share of remittances in GDP is significant (7.6\% between 2007 and 2011) and they cover nearly $40 \%$ of the trade deficit (the difference between the monetary value of imports and exports of goods and services) (Janković and Gligorić 2012).

According to some estimates, only between 10 and $50 \%$ of remittances are actually transferred through formal channels (Giuliano and Ruiz-Arranz 2009). In some countries the actual volume of remittance flows not registered officially or transferred through informal channels is often considered much greater than the estimates made by the relevant institutions, which only serves to underline the importance of remittances as a possible external source of financing consumption and investment in developing countries (Chami et al. 2008, 2009). The inflow of remittances into Serbia is at present estimated on the basis of formal inflows, primarily through the banking sector, while informal inflows are approximated primarily using the volume of activity of foreign currency exchange services.

In spite of the dearth of responses, the findings of the Survey on Conditions for Doing Business in Serbia are significant, since this is one of the first studies to date on the possible impact of remittances on Serbia's economy. ${ }^{21}$ All entrepreneurs whose households receive remittances from abroad claimed they did so via bank accounts. As expected, no informal channels were mentioned. Entrepreneurs who responded came predominantly from the trade and other services sectors, and primarily represented small businesses with up to 4 or between 5 and 19 employees. Although few entrepreneurs confirmed they did receive remittances from abroad, they claimed that they used the money mainly to start or carry on operations (77\% of all entrepreneurs' households that received remittances). Interestingly enough, only $34 \%$ of the funds received had been used for consumption, while as much as $66 \%$ had been employed in business. It is also important to note that funds from remittances have been used in business for some time now. Entrepreneurs who had employed such funds over the previous year made up $23 \%$ of those who received remittances. A total of $32 \%$ of respondents stated that they had been using

\footnotetext{
${ }^{20}$ The World Bank defines migrant remittances as the sum of workers' remittances, employee compensation, and migrants' transfers. Under the IMF Balance of Payments Manual, 6th Edition (IMF 2010), workers' remittances are defined as personal transfers of migrant workers residing in the country in which they work. Residence is assumed to be where a worker remains abroad for 1 year or more, while income earned during shorter stays abroad is categorised as employee compensation. Migrant transfers represent the net value of the assets of migrants transferred from one country to another during their migration for a period of at least 1 year. The recipients of these assets reside in their country of origin.

${ }^{21}$ An attempt was made by the Statistical Office of the Republic of Serbia to study and analyse the inflows of remittances into Serbia. This was an ad hoc survey into unregistered remittances carried out as part of a regional project aimed at assessing a portion of the unreported economy.
} 
remittances in business for 6-10 years, while $15 \%$ claimed that they had used remittances in business for more than 10 years. Remittances are most often used to purchase current assets, which is only logical in these activity sectors. These findings are particularly relevant since it is certain that a substantial portion of remittances is transferred through informal channels, which increases the amount of funds potentially available for investment, notwithstanding the fact that the respondents did not formally substantiate this assumption.

Open Access This chapter is distributed under the terms of the Creative Commons Attribution Noncommercial License, which permits any noncommercial use, distribution, and reproduction in any medium, provided the original author(s) and source are credited.

\section{References}

Abdih Y, Chami R, Gapen M, Mati A (2009) Fiscal sustainability in remittance dependent economies. IMF Working Paper WP/09/190. International Monetary Fund, Washington, DC

Abdih Y, Barajas A, Chami R, Ebeke C (2012) Remittance channels and fiscal impact in the Middle East, North Africa, and Central Asia. IMF Working Paper WP/12/104. International Monetary Fund, Washington, DC

Adams RH, Page J (2005) Do international migration and remittances reduce poverty in development countries? World Dev 33(10):1645-1699

Alm J, Jackson B, McKee M (1992) Estimating the determinants of taxpayer compliance with experimental data. Natl Tax J 45(1):107-114

Arandarenko M, Avlijaš S (2011) Behind the veil of statistics: Bringing to light structural weaknesses in Serbia. In: Schmidt V, Vaughan-Whitehead D (eds) The impact of the crisis on wages in South East Europe. ILO, Budapest

Arandarenko M, Stanić K (2006) Labor costs and labor taxes in Serbia. Background paper for World Bank report. Labor market assessment, Serbia

Arsić M, Ranđelović S, Pejić M (2012) Reform of the system of Quasi-Fiscal charges for the improvement of business conditions in Serbia. Quarterly Monitor, vol 29, April-June 2012

Chami R, Barajas A, Cosimano T, Fullenkamp C, Gapen M, Montiel P (2008) Macroeconomic consequences of remittances. IMF Occasional Paper No 259. International Monetary Fund, Washington, DC

Chami R, Barajas A, Gapen M, Fullenkamp C, Montiel P (2009) Do workers' remittances promote economic growth? IMF Working Paper WP/09/153. International Monetary Fund, Washington, DC

De Soto H (1989) The other path. Harper and Row, New York

De Soto H (2000) The mystery of capital: why capitalism triumphs in the west and fails everywhere else. Basic Books, New York

Enste DH (2010) Regulation and shadow economy: empirical evidence for 25 OECD-countries. Constit Polit Econ 21:231-248

Fiscal Council (2012) Predlog mera fiskalne konsolidacije 2012-2016

Friedman E, Johnson S, Kaufmann D, Zoido-Lobatón P (2000) Dodging the grabbing hand: the determinants of unofficial activity in 69 countries. J Public Econ 76:459-493

Giuliano P, Ruiz-Arranz M (2009) Remittances, financial development and growth. J Dev Econ 90 (1):144-152

GIZ (2010) Addressing tax evasion and tax avoidance in developing countries. Study prepared by GIZ and the German Federal Ministry of Economic Cooperation and Development

IMF (2010) Balance of payments manual, 6th edn. International Monetary Fund, Washington, DC 
IMF (2011) Republic of Serbia: request for stand-by arrangement, IMF Country Report 11/311. International Monetary Fund, Washington, DC

Irving J, Mohapatra S, Ratha D (2010) Migrant remittance flows: findings from a global survey of central banks. Working Paper 94. The World Bank, Washington, DC

Janković I, Gligorić M (2012) Remittances as a stable source of foreign currency inflow in Serbia. In: Jovanović-Gavrilović B, Rakonjac Antić T, Stojanović Ž (eds) Thematic collection of papers "Economic Policy and Development". Faculty of Economics, Belgrade, pp 215-236

Johnson S, Kaufmann D, Zoido-Lobaton P (1998) Regulatory discretion and the unofficial economy. Am Econ Rev 88(2):387-392

Koettl J (2012) Does formal work pay in Serbia? The role of labor taxes and social benefit design in providing disincentives for formal work. In: Laderchi CR, Savastano S (eds) Poverty and exclusion in the Western Balkans. New directions in measurement and policy, vol 8. Springer

Kovtun D, Cirkel AM, Murgasova Z, Smith D, Tambunlertchai S (2014) Boosting job growth in the Western Balkans. IMF WP/14/16

Krstić G, Sanfey P (2011) Earnings inequality and the informal economy: evidence from Serbia. Econ Transit 19(1)

Loayza N, Oviedo AM, Serven L (2006) The impact of regulation on growth and informality, cross-country evidence. In: Guha-Khasnobis B, Kanbur R, Ostrom E (eds) Linking the formal and informal economy, concepts and policies. Oxford University Press, Oxford

NALED (2012a) Businesses can run, but they cannot hide - the system of non-tax and para-fiscal charges in Serbia: inventory, analysis of effects and recommendations for reform

NALED (2012b) Siva knjiga 5 - Preporuke za uklanjanje administrativnih prepreka za poslovanje u Srbiji 2012/2013

NBS (2012) Report on the Dinarisation of the Serbian financial system. www.nbs.rs

OECD (2008) Serbia - a labour market in transition. OECD, Paris

Radulović B (2011a) Merenje administrativnih troškova primenom modela standardnog troška Kritički osvrt i moguća poboljšanja. u S. Tabaroši, ur. "Razvoj pravnog sistema Srbije i harmonizacija sa pravom EU". Pravni Fakultet, Beograd

Radulović B (2011b) Standard cost model - baseline measurement. Serbia, Mimeo

Ranđelović, S, Đorđević A (2012) Unapređenje performansi malih i srednjih preduzeća u Srbiji kroz reformu sistema oporezivanja. Istraživački rad pripremljen za potrebe Istraživačkog foruma Evropskog pokreta u Srbiji

Schneider F (eds) (2011a) Handbook on the shadow economy. Edward Elgar, Cheltenham

Schneider F (2011b) The shadow economy in Europe - using payment systems to combat the shadow economy. http://www.bblf.bg/uploads/files/file_378.pdf

Schneider F, Enste D (2000) Shadow economies: size, causes and consequences. J Econ Lit 38 (1):77-114

Schneider F, Buehn A, Montenegro CE (2010) New estimates for the shadow economies all over the world. Int Econ J 24(4):443-461

Tedds LM (2010) Keeping it off the books: an empirical investigation of firms that engage in tax evasion. Appl Econ 42(19):2459-2473

Transparency Serbia (2012) Public comment periods in the Republic of Serbia - analysis of the statutory framework and practice

USAID (2005) Removing barriers to formalization: the case for reform and emerging best practice

USAID (2012a) Financing the growth of small and medium-sized enterprises: critical issues and recommendations for Serbia

USAID Business Enabling Project (2012b) Assessment of constraints to construction permits in Serbia

Williams CC (2006) The hidden enterprise culture: entrepreneurship in the underground economy. Edward Elgar, Cheltenham

World Bank (2009) Serbia - doing more with less: addressing the fiscal crisis by increasing public sector productivity. Report no. 48620-YU, Washington, DC

World Bank (2011) Republic of Serbia - country economic memorandum: the road to prosperity: productivity and exports, vol 2, Report no. 65845-YF, Washington, DC 